\title{
MAML1 Gene
}

National Cancer Institute

\section{Source}

National Cancer Institute. MAML1 Gene. NCI Thesaurus. Code C114485.

This gene is involved in notch-dependent gene expression. 